\title{
Health vocational schools' clinical courses of Medicine" double type" teachers' training strategy
}

\author{
Zhiyong ZHANG \\ Langfang Health Vocational College \\ Langfang,056000, China
}

\author{
Fangqiu LIU \\ Langfang Health Vocational College \\ Langfang,056000, China
}

\begin{abstract}
For health vocational colleges, the " double type " teachers training in clinical courses is an important part of teaching staff construction. Currently, the cultivation of the "double type" teachers in health vocational colleges still exists many problems, health vocational colleges should aim at these problems, formulate corresponding policies and measures, and through a variety of effective ways to strengthen the cultivation of "double type" teachers, make efforts to create a group of outstanding high-quality "double type" teachers, in order to protect the improvement of teaching quality in health vocational colleges education.
\end{abstract}

Keywords- health vocational colleges; clinical courses of Medicine; the double type teache;r training strategy

\section{INTRODUCTION}

This template provides authors with most of the formatting specifications needed for preparing electronic versions of their papers. All standard paper components have been specified for three reasons: (1) ease of use when formatting individual papers,

Promulgated in 2010 " the National Medium and Longterm Plan For Education Reform and Development ''(20102020), we clearly put forward the general requirements of strengthening the construction of "double type" teachers, improving the capacity of vocational education foundation. In 2002 after the national education work conference, our country raised a hot wave of the development of vocational education, its scale expanded unceasingly, but overall, the" double type" teacher who lacked of professional theoretical knowledge and high teaching level and had the strong ability practice teaching, had become a serious "bottleneck" restricting the development of vocational education. In domestic higher vocational education, the cognizance of "double type" teachers has reached a unified way, the "double type" teacher, refers to not only has the teacher achieved strong ability of teaching and professional theoretical level, gained the education system in the field of teachers' qualification certificate, but also it has the professional or professional qualification certificate of the teachers in the corresponding industry, or it has engaged in the professional practice work experience, and strong practical application ability. Health professional education has no exception, the health vocational education is training "practical" medical talents, it requires that health vocational colleges must have a strong theoretical knowledge and rich experience in teaching, and have skilled clinical operational skills of the "double type "teachers.

\section{THE MEDICAL PROBLEMS OF "DOUBLE TYPE" TEACHERS IN HEALTH VOCATIONAL COLLEGES}

A. A severe lack of the clinical courses "double type" teachers, we can't meet the needs of the teaching

Vocational education has developed rapidly in our country, the scale of higher education institutions has been continuously growing, while the vocational education teachers team construction is far behind the development of vocational education, it can't meet the requirements of teaching, pupil-teacher ratio is generally on the high side. In 2006, the independently established higher vocational colleges has 283,000 full-time teachers, pupil-teacher ratio was 18.3:1 in full-time teachers, the "double type" teacher was 72,000 people, only $25.5 \%$, and this is far from the ministry of education requirements of the "double type" teachers proportion about $50 \%$. Health vocational schools are also in the same predicament, a grave shortage of "double type" teachers in clinical courses, it cannot satisfy the needs of teaching, and seriously influence the improvement of teaching quality in health vocational colleges.

\section{B. The single source of "double type" teachers in clinical} courses, the low level of clinical practice

Health vocational colleges' most teachers in clinical courses, are graduated from medical school (college) to work in the medical school (college) directly, without the systematical clinical practice, the low level of clinical practice [2], the clinical courses in "double type" teachers team construction is congenitally deficient. While the ratio of the teacher who come from clinical front line, has rich clinical experience and skilled operation skills of clinical courses is low. This situation is not conducive to the clinical courses" " double type "teachers team construction in health vocational colleges.

\section{The "double division type" teacher training hard, restricts the development of health vocational colleges}

General health vocational colleges have no affiliated hospital, even it has, the most exists in the clinic or outpatient service form, the equipment is humble, the clinical course of " double type "teachers in the school (college) in 
practice the lack of opportunity; Secondly, with the enlargement of enrollment scale, teachers' daily teaching work also gradually increased, the teachers are busy in teaching every day, the energy is limited, and they can't insist on a regular basis to the hospital or the center of Beijing, Tianjin and other places in the city of some big hospitals for clinical studying. Furthermore, there has been no special the clinical course of" double type "teachers' training bases. Thus, a "double type" teacher in training has its difficulties, and this seriously restricts the development of health vocational colleges.

\section{The clinical course of "double type" teachers' lack of supporting policies, inhibit the enthusiasm of teachers}

At present most health vocational colleges in " double type "teachers' training incentive and no specially formulated effective measures to support, dampened the enthusiasm of teachers and initiative. Many teachers tend to pay attention to their own record of formal schooling and title promotion, and pay less attention to the cultivation of their clinical practice level and improvement, often can't (or wouldn't) to go to the hospital for clinical practice. School (college) hospital cooperation, on the other hand, lacking of policy support, the school (college) court not closely combine, and this inhibits the teachers' work enthusiasm. As a result, the "double type" teachers could not effectively improve the clinical level; the teaching quality will be affected.

\section{E. Double type teachers' part-time teachers lacks of relative stability, this influence the improvement of teaching quality}

Because the number of "double type" teachers cannot satisfy the needs of teaching, most health vocational schools will hire some physicians as part-time teachers who have rich clinical experience in clinical from the city hospitals. However, these part-time teachers lack the knowledge of professional education teaching theory, and do not have enough teaching experience; Due to the influence of clinical work, the energy shortage is in the teaching, the teaching material, teaching methods, students' research is not enough; In addition, the health vocational colleges existence of parttime teachers' employment system is not perfect, imperfect management system, etc., It can't fully arouse the enthusiasm of part-time teachers, at the same time, it can't attract more clinician to do part-time job. Therefore, the part-time job in the clinical courses of the teaching staff lacks of relative stability, affects the improvement of teaching quality.

"Double type" teachers itself also has some problems. Such as young teachers, just have a job soon, is likely to be one's deceased father grind, continue his master's degree, marry oneself and have children, don't have much energy to go to the hospital, and the opportunity to practice is less, clinical skills levels increase slowly; And for senior teachers will be lazy because teaching work time is long, plus lack of enough energetic, health and other reasons, they can not insist on a regular basis to the hospital for clinical training, clinical practice level decreased, and so on. These factors also influence the health vocational colleges' "double type "teachers' training.

\section{THE HEALTH VOCATIONAL COLLEGE'S MEDICAL OF "DOUBLE TYPE "TEACHERS TRAINING METHODS AND STRATEGIES}

\section{A. Improve the "double type" teachers' training system, strengthen the teacher training}

Health vocational colleges is to improve the " double type "teachers' training system, make efforts to improve teacher's professional accomplishment theory, practical teaching abilities and skills operation level. The ways of training mainly includes: in a planned way, send backbone teachers and to higher vocational education teacher training bases for training, improve their quality of "double division", to make them return to college (school) and to have the effect of demonstration and leading the way; Encourage teachers to obtain relevant professional technical position qualifications, professional skills/qualifications, etc., constantly improve their professional ability and quality; To encourage and support young teachers on-the-job or off-thejob master, doctor degree of education and learning, improve their level, the degree to meet the needs of the future vocational education; Actively encourage "double type" teachers to the university or the clinical courses of Beijing, Shanghai, Tianjin and other places studying some of the big hospital, and to give a certain amount of subsidies. Through school (college) training, training, school (college) courtyard cooperation in the form of going abroad for further study and training, and maximize the " double type "teachers' ability and quality.

\section{B. Strengthening the cooperation of the school (college) hospital, improve the clinical courses of "double type " teachers of clinical operation skill level}

Health professional colleges and universities to cultivate the clinical courses of the excellent" double type "teachers, we must be good with local conditions, large level of firstclass hospital to establish cooperation relations, strengthening the cooperation of the school (college) court, so the " double type" teachers' cooperation can go to the hospital for clinical skills training, improve the level of their clinical operation. Systematically arrange young teachers to the field work of exercise cooperation hospital, directly involved in the clinical first line of actual work, to make their clinical knowledge and hands-on ability improved effectively. Other teachers also should be regularly to the hospital to participate in clinical practice, in order to avoid from the long practice time, which causes the "double division type" teachers' "double division" quality decline [3].

\section{The establishment and development of affiliated hospital, it is the important measure of "double type "teacher training}

Health vocational colleges want to develop, establish their own a certain scale hospital. and this is undoubtedly a correct strategic decision. After having the large-scale hospital, the " double type " teachers can be absolutely go to his own hospital clinical exercise, not only can it improve the level of their clinical operation, accumulated the rich clinical 
experience, but also it can make their independent thinking and judgment ability improved. At the same time, the establishment of the affiliated hospital of teachers is also of great significance to improve the clinical practice teaching ability, it also gives students an internship, the place of learning, the students can go to their own hospital for clinical acquisition, improve the quality of personnel training.

\section{Establish and improve the "double type "teachers'} incentive mechanism, give full play to their enthusiasm

Health professional colleges and universities should constantly improve the clinical courses of " double type " teachers' training incentive mechanism. For example, in the teachers' professional technical position appraisal of teachers "double division" quality, "the double teacher" ability appraisal; In teachers' reform of personnel distribution system and performance salary, fully embodies the "double type" teachers' contribution [5]; To go to college, from senior hospital teachers for further study, the school should bear all study costs, and to give certain economic subsidies; For active behavior of studying further education teachers, tuition fees and reimbursement shall be provided, and reward fund for setting; The establishment of "double type" teachers training allowance, etc., are the necessary measures. In addition, in the title promotion, job promotion, salary bonus, offer certain policy tilt. So we can fully arouse the enthusiasm of teachers and stimulate their enthusiasm.

\section{E. Strengthening the construction of part-time teachers and management, promote the clinical courses of "double "of teachers}

Health professional colleges and universities should actively hire physicians as part-time teachers, who has rich clinical experience and can guide the practice teaching. To strengthen the construction of part-time teachers, alleviate the "double division type" teacher shortage pressure. But in terms of employment and management of part-time teachers, pay attention to the following questions: establish and perfect the system of part-time faculty recruitment, part-time teachers recruitment information database, establish the employment standards for part-time teachers seriously, preferential employment; Strictly controlled when hiring of part-time teachers, to conduct a comprehensive inspection, evaluation, and establish a mechanism for school (college) courtyard condominium; Organize regular part-time teachers learn vocational education theory, to strengthen the vocational education teaching ability training, to improve their teaching ability and level; Health professional colleges and universities should gradually improve part-time teachers incentive management mechanism, establish relevant policy to improve bonuses, treatment of part-time teachers, allowing them to devote herself actively in teaching work, and becomes a stable part-time teachers, at the same time, we also can attract more and better clinical physicians part-time teacher to school (college).

\section{F. The "double type "teachers should overcome their difficulties; improve their quality of" double division ".}

Young teachers arrange your time and get to the hospital for studying to improve clinical skills level, to satisfy the needs of the clinical course teaching. For older teachers, to adjust its own time, do both clinical and teaching job, to avoid the clinical practice level dropping, etc.

\section{CONCLUSIONS}

To sum up, in health vocational colleges, the clinical courses of " double type "teachers' culture still has problems in all its aspects, health vocational colleges should aim at these problems, actively explore a variety of ways to strengthen the cultivation of the " double type " teachers, to make a beneficial policy to improve the "double type" teacher quality, fully arouse the enthusiasm of the" double division type " teachers, make efforts to build a high quality of the" double type" teachers, improve school (college) education quality of teaching, provide feasibility to ensure health development of vocational colleges.

\section{ACKNOWLEDGEMENT}

This paper is in Langfang city, Hebei province education science " twelfth five-year" plan project topic "the Health Vocational Colleges the Clinical Courses of " double division type" teacher training strategy research" (host: Mr. Zhang project number: 112177)

\section{References}

[1] He Xiaoxiong. Higher vocational university-enterprise cooperation learning combined with $2+1$ the reform practice of talent training type $[\mathrm{J}]$. Journal of vocational and technical education in China, 2008(29).

[2] Fengxiang you, in the sound, step left. The concept of scientific development view of higher vocational colleges under the construction of "double type" teachers study[J]. Journal of vocational and technical education, 2011 (11) : $73 \sim 76$.

[3] Zhong-fu wang. Medical education reform and new requirements for clinical teachers professional[J]. Journal of health vocational education, 2003, 9 (10) : 101

[4] Dong Guilin ming-xing zhou. Vocational colleges "double type" teachers survival sickness and disease cure [J]. Journal of vocational and technical education, 2005 (4) : 52.

[5] Meng Lingchen Cao Ye. "double type" teachers in higher vocational colleges sampling analysis [J]. Journal of vocational and technical education in China, 2012 (9) : $63 \sim 67$. 